\title{
The Concept of "Person" in the Italian Legislation on Informed Consent and Advance Healthcare Directives
}

\author{
Matteo Cresti $^{1}$ (D)
}

Accepted: 31 December 2020 / Published online: 10 February 2021

(C) The Author(s) 2021

\begin{abstract}
The aim of the paper is that of investigating the concept of "person" in the context of Italian law on informed consent and advance healthcare directives (law $\mathrm{n}$. 219/2017). The following paper will first consider the importance of the concept of "person" within bioethics; secondly it will exhibit how there are different levels of bioethics, and that on the discussion level of laws and regulations, concepts worthy of metaphysical and value references cannot be used, because they must be shared by everyone in a pluralistic society. I'll then move on to discuss the law on informed consent and advance healthcare directives; first I'll discuss the references to the Italian Constitution, showing that the implied concept of "person" is closely linked to the concepts of "equality" and "autonomy", and finally I'll discuss the particular case of minors and the protection that the law provides them.
\end{abstract}

Keywords Person · Informed consent · Constitutional law · Italian legislation · Bioethics

\section{The Importance of the Concept of "Person" within Bioethics}

This paper investigates the concept of "person" within the recent Italian legislation on bioethical issues. Both law and philosophy use the concept of "person", but differently. Here I want to explain why the law cannot use the concept of "person" in the philosophical sense, and which is the meaning of the concept employed by law. Often the starting point in the discussion of the law is ethics. However, the legislation in a liberal society cannot openly assume ethical and philosophical concepts that directly reference a specific metaphysical or moral vision. Clarifying the meaning of the concept of "person" employed by law helps to understand what survives of its philosophical meaning. Indeed, the concept of "person" is often used in various contests but with different meanings. Understanding how the term "person" is

Matteo Cresti

matteo.cresti@unito.it

1 Department of Computer Science, University of Turin, Turin, Italy 
used in various contexts, and more precisely what it refers to within the legal context, increases the understanding of the legal system itself and the rights [1,2].

The concept of "person" is widely used in philosophical bioethics. Some issues studied by this discipline almost exclusively concern the concept of "person". Consider, for example, the problem of abortion: the voluntary termination of a pregnancy leading to the death of a fetus. In common-sense morality, murdering an innocent human person is prohibited. The problematic issue, therefore, becomes whether a fetus is a human person. Various metaphysical conceptions of the person and life collide in this field. The matter has always been presented as a dichotomy between two alternatives: "if the embryo is a person then abortion is not legal", versus "if the embryo is not a person then abortion is lawful" [3]. Resolving the issue requires establishing whether an embryo (or more so, a fetus) are to be considered a "person" or not. The ethical problem seems to take on metaphysical traits; or, in other words, it can be seen how metaphysical issues take on a strong role in the resolution of ethical problems.

On the one hand, the traditional approach of pro-life movements is that of attributing absolute importance and relevance to science. The argument can be summarized as follows: it is morally wrong to kill a human being; science establishes that an embryo is a human being; therefore, abortion is morally wrong. The political slogan of these movements is "the embryo is one of us", a slogan that underlines the equality between embryos and adults, and the participation of all of them in the same community (e.g., [4]). As is well known, this argument faces some objections, for example that the notions of "person" and "human being" are not coextensive: "human being" is a biological notion (a member of the homo sapiens species), and "person" is a philosophical or metaphysical notion, denoting the presence of intellectual and moral faculties.

Even the Roman Catholic Church itself, at least in its official position, has shown doubts regarding this argument: in fact, the Declaration on procured abortion establishes that "Right from fertilization is begun the adventure of a human life". However, it adds that "it is not up to biological sciences to make a definitive judgment on questions which are properly philosophical and moral such as the moment when a human person is constituted or the legitimacy of abortion" [5: $n$. 13]. Determining whether a fetus or embryo is a person is not a matter of biology, but metaphysics. The magisterium of the Roman Catholic Church has never expressed itself regarding the moment in which the soul is blown into the body: "This declaration expressly leaves aside the question of the moment when the spiritual soul is infused" [5: endnote 19]. However, the magisterium argues that the embryo should be treated "as a person" from the moment of conception [6: I, 1]. Therefore, abortion is still wrong because "it suffices that this presence of the soul be probable (and one can never prove the contrary) in order that the taking of life involve accepting the risk of killing a man, not only waiting for, but already in possession of his soul" [5: endnote 19].

On the other hand, some philosophers interpreted the concept of "person" as the presence of certain brain activities and rational abilities. Starting from a reductionistic approach, they identified the presence of a person when the organs that produce these capacities are present (brain and central nervous system) or begin to be 
present. Some of them, contrarily to the Catholic Church, legitimize not only abortion but also infanticide (e.g. [7, 8]).

Although from different points of view, both theories distinguish between "human being" and "person", with the latter meaning a being of high mental and spiritual capacities. Even for the Catholic Magisterium, the notion of "person" does not apply only to human beings, but also to angels and God, while for some secular philosophers it could also apply to some primates, or in any case to hypothetical extraterrestrials that could one day come to visit us.

Such different theories cannot converge and hardly achieve middle ground. In particular, elaborating a statement by philosopher Vanni Rovighi [9] who underlined how the answer to an ethical problem relies on the assumed conception of "person" and world view, some Catholic bioethicists have argued that the conceptions of what a person is are irreconcilable, and therefore productive dialogues are impossible [10, 11]. Hence, each conception should be left in its own philosophical field, and the only point of confrontation would therefore be that of politics, where the various conceptions collide in order to prevail upon others $[10,11]$.

\section{The Levels of Bioethics and Political Disagreement}

However, the possibility of an agreement mainly depends on the level of discourse. Bioethics has a particular nature because on the one hand it is a theoretical academic discipline and is subject to the rules of scientific debate, while on the other hand it is a part of public discourse, of a movement that has brought a new awareness regarding patients' rights and their bodies, issues which have been faced in city squares as much as in parliaments. In this sense, Jonsen [12] spoke of bioethics considered as "disciplines" and bioethics considered as "discourse".

However, it is possible to distinguish at least three levels of bioethics [13, 14], based on the purpose each level has. A first level is bioethics as an academic discipline or "philosophical bioethics". The goal of this type of research is to formulate a philosophical theory on ethical problems arising in clinical practice and biomedical research. The goal of philosophy is to consider the details of problems whilst trying to solve them, find the most justified theory possible. Philosophical bioethics therefore consists (or should consist) of a robust and justified theory, which is integrated into a broader philosophical system. In this sense, Catholic bioethicists are right in claiming it is impossible to find a consensus if the fundamental principles on which the theories have been built diverge.

The second level is "policy-oriented" bioethics. It is an agent of the political or organizational field. Its goal is not to reach the truth or the theory that has the most supporting justifications, but to reach an agreement between parties, to build policies, regulations, and laws.

Finally, the third level is cases analysis. An example of this practice may be the "God Commission" which at the Swedish Hospital in the early 1960s decided who could access dialysis and who was to be left out. They did not decide based on criteria, rather on a case-by-case rationale, based on considerations such as life expectancy, whether a patient had children, occupation, and so on. Only later on did they 
formulate a list of criteria to consider [12: 211-217]. Rather than proceeding topdown (starting from general principles that are then applied to the case) they proceeded bottom-up (analyzing cases and noting analogies between them, from which they could extract rules or general indications). This procedure is known in bioethics as casuistry [15].

As far as the following paper is concerned, the objective is that of analyzing the various conceptions of "person" within Italian legislation; for this reason, I'll further look into the second level of bioethics. The problem, therefore, becomes how laws and regulations should be built. Rawls defines an ideal procedure within a liberal democracy [16]. Rawls describes liberal society as composed of reasonable citizens characterized by cooperation, the stability of their society, and individual freedoms in mind. Each of them has their own conception of good and evil, of God, and has different values. Rawls calls this set of beliefs a "comprehensive doctrine", that is, a set of metaphysical and moral conceptions that give meaning to one's life, and that can be different among the various citizens. Since citizens are reasonable, they do not want to impose their comprehensive doctrine on others because they know that this would create divisions, would impose a restriction of individual freedoms, and in turn, they would not want to undergo such abuse by others. They should give "public reasons", embraceable by all. So, in order to be able to cooperate and stay in a fair society and guarantee the fundamental freedoms of each individual, they should seek an "overlapping consensus". Citizens get an overlapping consensus when they agree on a set of laws, each based on different reasons [16].

The formulation of legislation on bioethics also goes through a similar process (or at least it should). In this sense, Catholic bioethicists are therefore right in saying that an agreement can never be reached based on their comprehensive theories and that therefore the discussion on these comprehensive theories must take place within the community of researchers who support them. However, secular philosophers who claim that an agreement can be reached by discussing the most limited issues are also right. They leave the level of philosophical bioethics to enter that of policy-oriented bioethics.

This paper aims to analyze the concept of "person" emerging from some Italian bioethical laws, namely those law governing bioethical issues, such as abortion or informed consent. With regards to what has been considered above, one should not expect to find robust and structured metaphysical conceptions.

Italy became a Republic in 1946. A Constituent Assembly was created immediately after the end of the Second World War, with the objective of writing a Constitution inspired by democratic and anti-fascist principles. The same thing happened in Germany, with the drafting of the Basic Law. The history of republican Italy is more than seventy years long. During this period, Parliament and citizens have been called upon several times to decide on ethical and bioethical issues, an example being the approval of the divorce and abortion laws and subsequent confirmatory referendums in the late'70s. These laws were the product of a historical period of strong ethical and political movements and changes, such as the achievement of women's rights, societal secularization, and the advent of new technologies such as the birth control pill. 
The second season of legislative initiatives has taken place over the past two decades. Highlights of these twenty years have been the approval of the law on assisted reproduction, the public debate on the Welby and Englaro cases (see below), the legislation approving civil unions, and, most recently, the approval of the law on informed consent and advance healthcare directives. This twenty-year period has undoubtedly not been consistent throughout its course. It can be divided into two parts: on the one hand, the political era marked by the papacies of John Paul II and Benedict XVI, during which bioethical issues played a central role within the Church, leading the Church itself to take on rigorous stances on such issues and be active in public discourse. With the advent of Pope Francis, the emphasis of the discourse within the Church has shifted from bioethical to social issues, such as poverty, causing a less heated debate.

Given this significant disparity of contexts and settings, I will focus only on the last period and will examine law 219/2017, "Rules regarding informed consent and advance treatment provisions" [17], referring to the Italian Constitution and other laws on bioethics. Furthermore, this law summarizes and is closely related to all other laws on bioethics, so it can be considered a good case study to analyze the concept of "person" within Italian legislation.

\section{Informed Consent and Advance Treatment Provisions}

In Italy, informed consent is a "quite new practice". The first occurrence was in 1990 with the so called "Massimo landmark case", where a surgeon was found guilty of not having intervened against the will of the patient [10, 18, 19]. Instead in United States the earliest critics of the traditional Hippocratic conception the middle of nineteenth century $[20,21]$, while the earliest lawsuits were in the second decade of twentieth century (e.g., [22, 23]).

"Informed consent" means the practice of informing patients about their health and medical conditions, and enabling them to choose among the various therapeutic alternatives. In the Hippocratic corpus, there is no obligation to tell the truth: the patient does not need to be informed, and indeed, often, information must be kept hidden so as not to frighten her. More so, there is no mention of the patient's possibility of choosing: the doctor is the owner of medical knowledge, and therefore the physician knows what the patient's best interest is. It was taken for granted that consent was provided by the patient in the very moment in which she sought the physician's help. The physician had to do everything to save the patient's life since life is the greatest of goods.

Article 32 of the Italian Constitution states: "The Republic safeguards health as a fundamental right of the individual and as a collective interest, and guarantees free medical care to the indigent. No one can be obliged to undergo any health treatment except under the provisions of the law. The law may not under any circumstances violate the limits imposed by respect for the human person" [24]. This article, however, at least in the intentions of the authors of the constitution, did not intend to establish the patient's right to independently make choices regarding therapies. 
The affirmation of informed consent in Italy has been defined as a "silent revolution" [25], since its course has been slow and gradual. It accelerated with the Englaro and Welby cases, which brought public attention to the topic of informed consent in Italy. Actually, the public debate seemed to discuss these cases as if they were examples of euthanasia, when in reality it concerned the interruption of unrequired treatment on behalf of patients (e.g., [26, 27]). Piergiorgio Welby was a man affected by muscular dystrophy, due to which he was attached to a respirator. He asked for the machinery that kept him alive to be detached, which would have resulted in his death. The doctor who sedated Welby and disconnected the respirator was legally inquired upon both by the ordinary judiciary and by the Italian medical association. In both cases, it was established that the doctor had not acted contrarily to the law and the code of medical ethics, and this strengthened the principles of informed consent.

The case of Eluana Englaro was similar. Eluana was a young woman who was in a permanent vegetative state following a car accident. The woman had declared to her father and friends that she would never have wanted to remain in such a state. For this reason, the family members tried for 17 years in each competent court to obtain permission to disconnect artificial nutrition and hydration. Finally, after a long struggle, in 2008, the Appellate Court of Milan allowed her father's requests. The debate was even ruder than in the Welby case, with the Parliament being convened to approve an urgent decree-law to prevent the woman's death. Beyond the political issues (e.g., [28]), the case was significant for two reasons: the first is technical, and regards whether hydration and artificial feeding can be considered a medical treatment or not. The second-the one of interest as far as this paper is concerned-is that for the first time, it was clear that informed consent needed to be approached extensively: the declarations that one makes today can also be valid in the future when that person is no longer able to express them. These are "advance healthcare directives" or "living will".

The advance healthcare directive is configured just like an extension of informed consent. Through this tool, the moral autonomy of individuals is respected even in those conditions in which they cannot express their will, be it temporarily and permanently. It consists of a text or another type of document that can record the patient's will. In this document, the patient inserts her will regarding the healthcare treatments she wants to receive, in case she can no longer express it. The patient can also appoint a trusted person who decides in her place following the patient's value system.

However, in order for there to be a real informed consent (and consequently also real advance healthcare directives), there must be at least two preconditions. The first is that the choices should be expressed in freedom. Leaving aside all the metaphysical questions about the possibility of free will, freedom of choice is intended as the absence of constraint, that is, an external element that binds one's choice. If a choice is to be made, a choice must be possible. The second precondition concerns the ability to understand. It is said that consent must be "informed", meaning the decision must be taken after receiving all relevant information. In order for a choice to be considered genuinely informed, the person who makes it must understand the information that is given to her; to understand it, she must have the ability 
to understand. The patient must be "competent". This consequently excludes certain specific categories of individuals from the possibility of providing valid informed consent, such as infants or individuals with advanced dementia. For this reason, from a moral point of view, the concept of "person" becomes fundamental to fully understand informed consent and the advance healthcare directive: only people, that is, beings who possess rational and cognitive faculties, can provide valid informed consent.

After almost twenty years of debate, the Italian Parliament approved law no. 219/2017, which reaffirms the principle of informed consent and establishes advance treatment provisions. Although the law does not define the meaning of "person", it does provide indications on it and incorporates some of the previous considerations. At the time of its approval, the media hype was considerably less than that during notorious cases of previous years (such as Welby's and Englaro's) [29]; this allowed for a balanced law, shared by all ethical groups.

\section{Law 219/2017 and Constitutional Principles}

The first article of Law 219/2017 refers to some principles of the Italian Constitution and the Charter of Fundamental Rights of the European Union [17].

The articles of the Italian Constitution that are referred to are article 2, "The Republic recognizes and guarantees the inviolable rights of the person, both as an individual and in social groups where human personality is expressed"; article 13 concerning personal liberties: "Personal liberty is inviolable"; article 32, which concerns the right to health: "The Republic safeguards health as a fundamental right of the individual and as a collective interest, and guarantees free medical care to the indigent. No one can be obliged to undergo any health treatment except under the provisions of the law. The law may not under any circumstances violate the limits imposed by respect for the human person" [24]. These three articles are the legal basis on which the law takes form. They set down the inviolable rights of the human person.

The articles of the Charter of Fundamental Rights of the European Union [30] that are referred to are the first three; they concern human dignity (art. 1): "Human dignity is inviolable. It must be respected and protected"; the right to life (art. 2), and the right to the integrity of the person (art. 3) that expressly mentions informed consent: "(1) Everyone has the right to respect for his or her physical and mental integrity. (2) In the fields of medicine and biology, the following must be respected in particular: the free and informed consent of the person concerned, according to the procedures laid down by law". The first difference that must be noted between the two texts is that the Constitution speaks of "right of the person", instead the European Charter speaks of "human dignity". Although the Italian Constitution shares certain genealogical features with German Basic Law, it does not present "human dignity" as one of its main concepts, which is instead central and essential in the German one. Article 1 of the German Basic Law states: "Human dignity shall be inviolable. To respect and protect it shall be the duty of all state authority" [31]. This indication was then incorporated into 
the Charter of the European Union. We must, therefore, see if and how the two texts can be integrated.

As far as Italian law is concerned, some academics consider that the expression "human dignity" lacks real meaning; it has only a rhetorical and reinforcing function [32-36]. The expression "human dignity" is not widespread in the Italian Constitution (appearing only three times in relatively peripheral contexts), and can be read as a 'cheerful' expression which summarizes previously expressed rights without substantially adding to them. It only indicates the set of fundamental rights enshrined in the Constitution, i.e. equality (both formal and substantive, as stated in Article 3 of the Italian Constitution, which imposes both equality of all before the law without discrimination of sex, race, religion, and personal conditions, as well as substantial equality, making it the Republic's responsibility to remove all obstacles that prevent the full development of the human person), and various forms of freedom (such as that of movement, teaching, religion, forming a family, press). The term "human dignity" is vague, as it is not clear what it refers to. The concept of "human dignity" is a moral concept which has been imported into law. Whoever introduced it perhaps wanted to give the idea that human beings must be respected; but in order to achieve this goal, it was sufficient to introduce the concept of "person" and her rights [see 32].

It is no coincidence that the concept of "human dignity" finds its highest formulation in the German environment, and that for its correct interpretation one must refer to Kantian moral philosophy, which centers on respect for others as an end in itself and not as a simple means (see [37, 38]). Even in German Basic Law, the expression "human dignity" is difficult to interpret [39]. It can be interpreted as a limitation that prevents the degeneration of human beings to mere objects [40], or as a norm that prevents humiliation or offense to self-respect [41], or a guarantee of recognition of one's self-representation [42]. In truth, none of these interpretations can clarify the meaning of the expression "human dignity". Instead, the expression has often been used as a limit to individual choices (see [43-45]), as in the case of "dwarf-tossing": a game in which an adequately protected and consenting dwarf is launched as far as possible by participants. Various courts in multiple countries have ruled that this activity goes against human dignity (see [46, 47]).

Human dignity, therefore, presents two problems: on the one hand, it is too vague, and in legal texts there is no specification as to what it refers to. On the other hand, precisely due to this vagueness, it becomes a screen behind which one can hide specific comprehensive theories on what the human person is and what her value is. The notion of human dignity refers to different conceptions and is often used to uphold specific comprehensive theories or specific moral theories, as is the case of the debate on prohibition or legalization of euthanasia. Precisely because it contains the concepts of "person" (which as stated above can be interpreted in many ways) and "human dignity" (which is a specific moral notion), the concept of "human dignity" can be interpreted in various manners and often hides substantial moral and metaphysical concepts which are incompatible with public discourse. However, as shown by Rawls [16], laws should be stipulated only through public reasons, that is, reasons that, in principle, should be shared by everyone, because they do not refer to 
any comprehensive theory. The concept of "human dignity" seems understandable instead only through reference to defined ethics.

On the other hand, there are very few references to human dignity in the Italian Constitution. In article 3 it is said that "All citizens have equal social dignity and are equal before the law", meaning that citizens are not to be discriminated based on their profession and noble status (noble titles were abolished by a fourteenth transitory provision), nor on the characteristics that are listed thereafter: "sex, race, language, religion, political opinion, personal and social conditions". Article 36 states that workers have the right to a "free and dignified existence"; article 41 states that "Private economic enterprise is to be free. It may not be carried out against the common good or in such a manner that could damage safety, liberty and human dignity", precisely hinting at the concept of "dignified life", referred to in Article 3 with the "full development of the human person". Article 48 speaks of "moral unworthiness" which constitutes a cause of restriction of the right to vote, for crimes such as corruption, and all those penalties that entail being barred from public offices [24]. In these contexts, the reference to "human dignity" seems superfluous, and can be reduced to what the Constitution has already expressed. We can, therefore, put aside this concept and examine the one expressed in Article 2 of the Italian Constitution: the state recognizes all the inviolable rights of the person, an article that is also referred to by the law hereby examined [24].

The central notion, therefore, is that of "person" and respect for its fundamental rights. Rodotà, an eminent Italian jurist, highlighted that the affirmation of the concept of "person" has developed in recent times [48]. There was a transition in the post-second world war period from the notion of "subject" to that of "person". The notion of "subject" has a formal nature, it does not represent a person in flesh and blood, but only the unifying center of the rights and duties that invest it, or to put it in Kelsen's words [49: 174] "is not a human being, but the personified unity of the legal norms that obligate or authorize one and the same human being". Anyone can be a subject, just being the subject of duties and rights. This notion, therefore, is not anchored to anything outside of the law itself, so you can freely decide who is or who is not a subject. If all rights and duties are taken away from a part of the population, they will cease to be legal entities.

For this reason, in rewriting the Constitution in the late '40s, a more rigid concept was chosen: that of "person". The attribution of the status of "person" is independent from the ascription of rights and duties. Therefore, it is a title that cannot be removed with a legal act. I cannot say that a minority (a group of people of different colored skin or of different religion) are not "people" solely with a legal act, depriving them of rights or establishing that some rights do not apply to them. In order for a specific group of individuals not to be considered "people", there is a need for a robust external criterion to justify this act. The Italian Constitution then states that fundamental rights belong to the person, not to the citizen; that is, they are attributed to everyone regardless of whether they have political rights [34, 48].

From the "subject", a privileged individual who enjoyed some rights, these rights then expanded to other categories of individuals who claimed them as their own (for example workers' movements, or women's suffrage). The number of "subjects" has gradually increased, until the distinction between people has been eliminated and 
the recognition of equality of all has been established, leading to the adoption of the more inclusive and protective notion of "person". At a certain point, the equality of all was recognized through the recognition of common humanity.

Therefore, we can establish what the first indication of what a "person" is: she is a human being, which as stated in Article 3 of the Italian Constitution, is "without distinction of sex, race, language, religion, political opinion, personal and social conditions" [24]. Many philosophers and bioethicists have rejected the identification between "person" and "human being". However, humans make up a subset of people. In truth, not all human beings are a person. Law, on the other hand, embraces this identification. It does this because the purposes of ethics and law are different. Law needs to be clear, defined, does not tolerate gray areas, does not tolerate dilemmas, nor aporias. For this reason, defining people through the recognition of a universal nature seems to be the best option. Referring to human nature can be risky (e.g., [50]), therefore to avoid a naturalistic foundation (which in the past has produced discrimination rather than equality, for example racial and gender discrimination based on supposed biological differences), some law scholars prefer a foundation based on a value (e.g., $[49,51])$. In any case, the identification of "person" with "human being" is a position which finds overlapping consensus in almost all theories.

It therefore becomes a choice, an assumption of values, to recognize everyone's equality. Various reasons support this choice: the recognition of our being different both in terms of personal abilities and conditions as well as material conditions, and the need for cooperation and peaceful life, in which all those who cooperate in the community enjoy recognition of their right to exist. For this reason, the Italian Constitution attributes fundamental rights to all, and precisely for the recognition of our conditions, which are so dissimilar, it recognizes equality both as formal equality and as material equality.

The person emerging from the Italian Constitution is not disembodied or abstract. The Italian Constitution recognizes the concreteness of the material conditions of individuals. That is, the person is a real human being who works, has a body, has different social and economic conditions. Starting from article 2, the Constitution protects the rights of the person both as an individual and as a social being, that is, not only protecting the human being in her individuality, but also in her social relations, such as family, friends, the environment where she lives and works, and all the other relationships she can become part of. Since there is recognition or corporality, there is also recognition that this corporality can take place in the context of particular living conditions, such as being unable to make decisions, as in the case of minors and people with cognitive problems. Not only, but the person that the Constitution outlines is also free, that is, capable of making autonomous choices that must be respected, as required by article 13 of the Constitution.

This is, therefore, the person that emerges from the constitutional context, and this is the person considered by law 219/2017, a person who lives in a material context, a person who is capable of making choices that must be respected, but also a person that sometimes is unable to make them.

For this reason, law 219/2017 in article 1 paragraph 2 states "Treatment relationship between patient and physician should be promoted and valued, and is based on 
informed consent, a meeting point between the patient's decisional autonomy and the physician's expertise, responsibility and professional autonomy" [17]. Paragraph 3 of the same article clearly expresses the patient's right to be informed understandably and adequately regarding diagnosis and alternatives of treatment, and that she has the right to reject in whole or in part what the doctors suggest, as well as the possibility of appointing a trusted person to make choices for her [17]. Finally, according to paragraph 6 , the physician must respect the patient's will; this paragraph definitively establishes the patient's moral autonomy. The very same autonomy is also enjoyed by the patient in the case of an advance healthcare directive [17].

This first article allows to extrapolate one of the main characteristics of human beings according to Italian legislation: people are autonomous subjects. Each individual has its own set of values, and should be allowed to make choices based on it. Hence autonomy plays a decisive role both in this law and in the whole Italian legislation. Autonomy is the means through which lawgivers established respect for the person, respecting its specific individuality and its possibility of reaching its full potential.

In article 5 the law reaffirms the moral autonomy of the subject, establishing that care must be planned between patient and doctor, but also considers the family and social relationships in which the patient is inserted. In fact, with the patient's consent, her family members may also be involved in the planning of care [17]. Another characteristic of the person can be extrapolated from this article, that of a rational being, and that the mentioned relationships should not only be taken into consideration but also protected.

Lastly, it should be noted that this law does not take into account a philosophical problem regarding advance healthcare directives, which could instead be central in establishing their validity. Metaphysics discusses what the criterion for establishing personal identity is, that is, a criterion that establishes whether two people at different points in time are in fact the same person [52]. One of the most discussed and most valid criteria is psychological continuity: that is, a person is the same person she was ten years ago because she remembers being that person [53-55]. However, in the case of neurodegenerative diseases, such as Alzheimer's syndrome, these memories vanish to the point of making it doubtful whether the sick person is now really the same person she was ten years ago. It is therefore debatable whether those provisions have value at the present moment, in which all the memories of those who wrote them have vanished. The philosophical problem seems very far from being resolved. As I have written, the law needs defined criteria. Therefore, it seems reasonable that the law does not consider this problem and adopts a more rigid criterion to define personal identity.

A "person", according to the Italian Constitution (and Italian law, which is perfectly in line with the Constitution), is therefore a human being considered in its material aspect. The person is guaranteed the right to express their own moral autonomy, which can be considered as the right to make their own choices according to their set of values. This right takes into account that people have different living conditions, and that each of them deserves to be respected and safeguarded. It also considers that people may find themselves in a state of weakness or fragility due to the material conditions or health conditions they live in; even in these conditions 
the law enables them to make their own choices, through filling the gap which disadvantages them. This gap can be filled either through time designated to creating a relationship with medical staff, or taking emotional and family ties into account.

The law does not lay down a specific metaphysical conception of what a person is; rather, it establishes a moral conception of person which, in Rawls terms, can be accepted by all reasonable people with overlapping consensus. The conception of person in this context is based on the assumption of equality as a founding value, and on the recognition that in order for people to be indeed equal it is necessary to acknowledge their moral autonomy in choices regarding their own life, allowing for the respect of their set of values.

\section{Law 219/2017 and Minors and Non-competent Adults}

However, there are two groups of individuals who are excluded from informed consent: minors and non-competent adults. Law 219/2017 takes them into account in article number 3, which states "The minor or incapacitated person has the right to enhance their understanding and decision-making skills (...). She must receive information on the choices related to her health in a way that is suitable for her ability to be able to express her will" [17].

As far as minors are concerned, the law allows informed consent to be expressed by those who exercise parental responsibility. So, for adults who are no longer competent, guardians may express informed consent, possibly following previously stated indications or the patient's values. The most interesting case to analyze concerns minors. Article 2 of Law 219/2017 paragraph 2 specifies "The informed consent to the health treatment of the minor is expressed or refused by the parents or guardian taking into account the will of the minor, according to her age and her degree of maturity, and having as its purpose the protection of the psycho-physical health and life of the minor in full respect of her dignity" [17].

The problem now becomes what the expression "take into account" means. In clinical practice and many international papers, minors are not asked for a valid "informed consent" but "assent". How "assent" is defined varies, but basically, it is an agreement to participate in clinical trials that do not require a full understanding of the study and the consequences of participation [56]. For example, article 29 of the Helsinki Declaration suggests that "When a potential research subject who is deemed incapable of giving informed consent is able to give assent to decisions about participation in research, the physician must seek that assent in addition to the consent of the legally authorized representative. The potential subject's dissent should be respected" [57].

A problem with the concept of "assent" is that it is not a clear notion [58]. The various codes and regulations offer different definitions. The objection that can be made is that the request for "consent" is useless. Mature minors can provide full informed consent; in fact, there are legal instruments in various States that allow emancipation from guardians' consent. Instead, minors who are not mature require someone else to do it for them. If the will of legal representatives can bypass the will of the minor, it is not clear what it means for them to ask for their consent. 
Asking for consent means treating the minor as an equal, assessing the person not in her abstractness, but in her corporeality, in her being not yet fully mature. Therefore, the law offers the minor the opportunity of enhancing her own abilities, which will then be integrated with those of her parents; as if informed consent were the sum of the minor's will plus that of her parents, thus completing the minor's incomplete ability of expressing consent.

The Italian courts have repeatedly acknowledged that full decision-making autonomy should be attributed to adequately mature minors over the age of 16 . As in some particular cases, decision-making autonomy (and the possibility of expressing valid consent) is also guaranteed to minors. Driven by these considerations, guidelines were issued for the acquisition of genuine informed consent for minors regardless of age, taking into account only decision-making and understanding competence [59].

Asking minors for informed consent or binding opinions is already a practice in many areas, even if there is no legislation on it [60]. For example, minors over 16 who are considered mature and competent are allowed to marry. In this case, the law speaks of "emancipated minor" [61: art. 394], or in the case of voluntary abortion [62] or in the case of testing for sexually transmitted diseases [63].

Unlike ethics, which can recognize the different nuances, in order to be effective the law needs to recognize a fixed limit to establish who is responsible for her actions and who is not, who is a full citizen in virtue of being competent and responsible and who is still not because she is a "person in training". However, there are margins which allow the acknowledgment of particular cases, in which maturity is not dependent on age and is instead reached much earlier. In particular, the laws acknowledge the autonomy and individuality of the minor in cases that significantly affect his body, her sexuality, and his affections and her relationships, to further emphasize the constitutional principles of equality and freedom.

\section{Conclusion}

The paper aimed to show the concept of "person" that emerges from Italian law 219/2017 regarding informed consent and advance treatment provisions, and from the texts to which this law is connected. I started by recalling the importance of the concept of "person" for bioethics. I have shown that bioethics can be divided into at least three types of discourse: a philosophical one, which seeks deep and solid justifications, a policy-oriented bioethics that has as its objective the construction of laws and regulations, and finally a practical bioethics which focuses on solving concrete cases.

I have shown that bioethics, which aims at the drafting of laws, cannot make use of what Rawls had called "comprehensive theories", that is, references to philosophical anthropologies, metaphysical assumptions, and value structures which are too biased. The reasons offered should, in principle, be public reasons, shared by all, in order to obtain an overlapping consensus. For this reason, a comprehensive theory of what a "person" is cannot be used in constructing a law regulating informed consent. 
Finally, I analyzed law 219/2017, first regarding the constitutional text and then concerning issues relating to minors. Regarding the constitutional text, I pointed out that the references to "human dignity" can be ignored, as they don't play a central role in the Constitution. These references are the result of the influence of other charters, are vague, and express nothing; they aim only at strengthening the rights and protections rhetorically already specified.

The "person" that emerges from reading the Italian Constitution and law $219 / 2017$ is, therefore, a human being, and not necessarily a citizen, since fundamental rights are attributed to each individual in recognition of common humanity. This commonality is not based on a natural datum, but on the recognition that we are all different and unequal, and that the acknowledgement of equality is functional to the achievement of coexistence and cooperation. Human beings are therefore recognized as people, without difference of race, sex, religion, and other personal conditions. Nevertheless, above all, they must be able to reach fulfillment. That is, they are autonomous beings, whose freedom must be respected, and which is guaranteed by many articles of the Constitution.

In this context, informed consent (and its extension, advance directive) allow the individual to express their individuality and therefore their equality in the eyes of the law. They allow respect for individuality, for each person's differences, for their relationships, and above all, for their moral and decision-making autonomy. That is, the law guarantees respect for the human person in her constitutionally established fundamental rights, or in a more poetic way, guarantees respect for her dignity. Similarly, the law also safeguards the autonomy of minors. In fact, on the one hand, it provides mature children the possibility of emancipation and expressing informed consent; on the other hand, it still establishes the enhancement of her abilities, that is, of her not yet fully achieved humanity, and of her will.

Funding Open Access funding provided by Università degli Studi di Torino. Research founded by ERDF ROP 2014-2020, Piedmont Region, "CaNP - La Casa Nel Parco"

\section{Compliance with Ethical Standards}

Conflict of interest The authors declare that they have no conflict of interest.

Open Access This article is licensed under a Creative Commons Attribution 4.0 International License, which permits use, sharing, adaptation, distribution and reproduction in any medium or format, as long as you give appropriate credit to the original author(s) and the source, provide a link to the Creative Commons licence, and indicate if changes were made. The images or other third party material in this article are included in the article's Creative Commons licence, unless indicated otherwise in a credit line to the material. If material is not included in the article's Creative Commons licence and your intended use is not permitted by statutory regulation or exceeds the permitted use, you will need to obtain permission directly from the copyright holder. To view a copy of this licence, visit http://creativecommons.org/licen ses/by/4.0/. 


\section{References}

1. Broekman, Jan M. 2007. Trading signs: Semiotic practices in law and medicine. International Journal for the Semiotics of Law 20 (3): 223-236.

2. Beever, Jonathan. 2012. Meaning matters: The biosemiotic basis of bioethics. Biosemiotics 5 (2): $181-191$.

3. Johnson, L. Syd M. 2004. Abortion contemporary ethical and legal aspects: Ethical perspective" In Encyclopedia of Bioethics, ed. Post Stephen G, 7-18. Macmillan, New York.

4. Gambassi, Giacomo. 2013. L'Europa vota la vita. L'embrione uno di noi, è l'ora di firmare. Avvenire, 7th January 2013. https://www.avvenire.it/famiglia-e-vita/pagine/embrione-uno-di-noi. Accessed 02 April 2020.

5. Sacred Congregation for the Doctrine of the Faith. 1974. Declaration on procured abortion, https:// www.vatican.va/roman_curia/congregations/cfaith/documents/rc_con_cfaith_doc_19741118_decla ration-abortion_en.html. Accessed 2 April 2020.

6. Sacred Congregation for the Doctrine of the Faith. 1987. Instruction on respect for human life in its origin and on the dignity of procreation replies to certain questions of the day, https://www. vatican.va/roman_curia/congregations/cfaith/documents/rc_con_cfaith_doc_19870222_respect-forhuman-life_en.html. Accessed 02 April 2020.

7. Tooley, Michael. 1972. Abortion and infanticide. Philosophy and Public Affairs 2 (1): 37-65.

8. Giubilini, Alberto and Francesca Minerva. 2013. After-birth abortion: Why should the baby live? Journal of Medical Ethics 39 (5): 261-263.

9. Vanni Rovighi, Sofia. 1963. Elementi di filosofia. La natura e l'uomo, vol. III, Brescia: La Scuola.

10. Mori, Maurizio. 2015. Manuale di Bioetica. Verso una civiltà biomedica secolarizzata. Florence: Le Lettere.

11. Sgreccia, Elio. 1994. Manuale di Bioetica. Fondamenti ed etica biomedica, Milan: Vita e Pensiero.

12. Jonsen, Albert R. 1998. The birth of bioethics. Oxford-New York: Oxford University Press.

13. Arras, John. 2003. The owl and the caduceus: Does bioethics need philosophy? In The nature and prospects of bioethics: Interdisciplinary perspectives, ed. F.G. Miller, J.C. Fletcher, and J.M. Humber, 3-5. Totowa, NJ: Humana Press.

14. Arras, John. 2016. Theory and bioethics. In The Stanford Encyclopedia of Bioethics, ed. Zalta E. N., https://plato.stanford.edu/entries/theory-bioethics/. Accessed 02 April 2020.

15. Jonsen, Albert R., and Stephen Toulmin . 1988. The abuse of casuistry a history of moral reasoning. Berkeley: University of California Press.

16. Rawls, John. 1993. Political liberalism. New York: Columbia University Press.

17. Law n. 219/2017, 22nd December 2017, https://www.gazzettaufficiale.it/eli/id/2018/1/16/18G00 006/sg. Accessed 02 April 2020.

18. Court of Assizes of Florence, sentence 18th 1990, president Sechi. Il foro italiano, 114: 236-244.

19. Selvatici, Franca. 1990. Una lunga agonia, poi la morte. Chirurgo condannato a 7 anni. La Repubblica, 19 October, https://ricerca.repubblica.it/repubblica/archivio/repubblica/1990/10/19/una-lunga -agonia-poi-la-morte-chirurgo.html. Accessed 02 April 2020.

20. Hooker, Worthington. 1849. Physician and patient or a practical view of the mutual duties, relations and interests of the medical profession and the community. New York: Baker and Scribner.

21. Faden, Ruth and Tom L. Beauchamp. 1986. History and theory of informed consent. New YorkOxford: Oxford University Press.

22. Schloendorff v. Society of New York Hospital. 1914. 105 N.E. 92, N.Y.

23. Salgo v. Leland Stanford, Jr. University Board of Trustees. 1957. 154 Cal. App. 2d 560317 P. 2 d 170.

24. Constitution of the Italian Republic. 1948. https://www.senato.it/documenti/repository/istituzione/ costituzione_inglese.pdf. Accessed 02 April 2020.

25. Immacolato, Mariella. 2004. La rivoluzione silenziosa nella medicina italiana. Consenso informato e comitati etici. Notizie di Politeia 20 (75): 35-59.

26. Politi, Marco. 2012. Welby suicida di seconda classe. Il Fatto Quotidiano, 17th April 2012.

27. Rome Vicariate. 2006. Comunicato Stampa. 22nd October 2006, http://www.romasette.it/uploa ds/57f117c3-14f6-e969.pdf. Accessed 02/04/2020.

28. Damilano, Marco. 2019. Eluana Englaro, quella sera nel Palazzo morì anche la pietà. L'Espresso, 8th February 2019. Accessed 2 April 2020.

29. Rodari, Paolo. 2017. Biotestamento, l'alt di Ruini: "Così si apre all'eutanasia”. La Repubblica, 15th December 2017. Biotestamento, l'alt di Ruini: "Così si apre all'eutanasia”. Accessed 2 April 2020. 
30. Charter Of Fundamental Rights Of The European Union. 2000. https://www.europarl.europa.eu/ charter/pdf/text_en.pdf. Accessed 02 April 2020.

31. Basic Law for the Federal Republic of Germany. 1949. https://www.gesetze-im-internet.de/engli sch_gg/englisch_gg.pdf. Accessed 02 April 2020.

32. Pocar, Valerio. 2012. Dignità e non-dignità dell'uomo. Ragion Pratica 38 (1): 119-128.

33. Monaco, Giuseppe. 2011. "La tutela della dignità umana: sviluppi giurisprudenziali e difficoltà applicative. Politica del diritto. 42 (1): 45-77.

34. Ferrajoli, Luigi. 2018. Manifesto per l'uguaglianza. Roma-Bari: Laterza.

35. Pirozzoli, Anna. 2007. Il valore costituzionale della dignità umana: un'introduzione. Roma: Aracne.

36. Cattinari, Enrico Bertrand. 2011. Dignità umana: obbligo di rispetto o contenuto prescrittivo? Note su un recente convegno. Sociologia del diritto. 11 (2): 179-192.

37. Ansuátegui Roig, Francisco Javier. 2012. Diritti fondamentali e dignità umana. Ragion Pratica 38 (1): 11-23.

38. Marzocco, Valeria. 2013. La dignità umana tra eredità e promesse. Rivista di Filosofia del Diritto 2 (2): 285-304.

39. Seelmann, Kurt. 2012. La tutela della dignità umana: garanzia di status, divieto di strumentalizzazione, oppure divieto di umiliare? Ragion Pratica 38 (1): 45-59.

40. Dürig, Günter. 1956. Der Grundsatz von der Menschenwürde. AöR 81: 117-157.

41. Balzer, Philipp, Klaus P. Rippe, and Peter Shaber. 1998. Menschenwürde vs. Würde der Kreatur. Menschenwürde vs. Würde der Kreatur. Freiburg: Alber.

42. Seelmann, Kurt. 2004. Repräsentation als element von menschenwürde. Studia Philosophica 63: 141-158.

43. Gemma, Gladio. 2012. Costituzionalismo liberaldemocratico e dignità imposta. Ragion Pratica 38 (1): $129-142$.

44. Gutmann, Thomas. 2012. La dignità curata: diritti e capacità del malato. Ragion Pratica 38 (1): 61-74.

45. Ferrajoli, Luigi. 2019. Dignità e libertà. Rivista di filosofia del diritto 8 (1): 23-32.

46. Azzoni, Giampaolo. 2012. Dignità umana e diritto privato. Ragion Pratica 38 (1): 75-97.

47. Belvisi, Francesco. 2012. Dignità umana: una ridefinizione in senso giuridico. Ragion Pratica 38 (1): 161-179.

48. Rodotà, Stefano. 2007. Dal soggetto alla persona Trasformazione di una categoria giuridica". Filosofia Politica 21 (3): 365-377.

49. Kelsen, Hans. 1967. Pure theory of law. Berkeley-Los Angeles: University of California Press.

50. Salardi, Silvia. 2015. Human nature a feasible benchmark for discussing the legal approach to old and new forms of discrimination? Rivista di Filosofia del Diritto 4 (1): 197-224.

51. Dworkin, Ronald. 2011. Justice for hedgehogs. Cambridge (MA): Harvard University Press.

52. Noonan, Harold. 1993. Personal identity. Dartmouth: Aldershot.

53. Locke, John. 1796. An Essay Concerning Human Understanding. London: Longman.

54. Shoemaker, Sydney. 1970. Person and their past. American Philosophical Quarterly 7 (4): 269-285.

55. Parfit, Derek. 1984. Reasons and persons. Oxford: Oxford University Press.

56. Jongsma, Karin, Wendy Bos, and Suzanne Van de Vathorst. 2015. Morally relevant similarities and differences between children and dementia patients as research subjects: Representation in legal documents and ethical guidelines. Bioethics 29 (9): 662-670.

57. World Medical Association. 2013. Declaration of Helsinki in Ethical Principles for Medical Research Involving Human Subjects as amended by the 64th WMA General Assembly, Fortaleza, Brasil, https://www.wma.net/policies-post/wma-declaration-of-helsinki-ethical-principles-for-medic al-research-involving-human-subjects/. Accessed 02 April 2020.

58. Baines, Paul. 2011. Assent for children's participation in research is incoherent and wrong. Archives of Diseases in Childhood 96 (10): 960-962.

59. Nave, Elena, et al. 2019. Procedura del consenso informato al trapianto di polmoni nei pazienti minorenni. Bioetica. Rivista Interdisciplinare 27 (1): 95-156.

60. Bo, Marco. 2019. La voce del minore: ambiti nei quali è già considerata preminente o significativa. Bioetica Rivista Interdisciplinare 27 (1): 206-219.

61. Civil Code, https://www.brocardi.it/codice-civile/. Accessed 02 April 2020.

62. Law n. 194/1978, 22nd May 1978, https://www.normattiva.it/uri-res/N2Ls?urn:nir:stato:legge:197805-22;194. Accessed 02 April 2020. 
63. Law n. 135/1990, 5th June 1990, http://www.trovanorme.salute.gov.it/norme/dettaglioAtto?id=14925. Accessed 02 April 2020.

Publisher's Note Springer Nature remains neutral with regard to jurisdictional claims in published maps and institutional affiliations. 